\title{
Climate change does not impact on Coffea arabica yield in Brazil
}

\author{
Williams PM Ferreira, ${ }^{\mathrm{a}^{*} \odot}$ José I Ribeiro Júnior $^{\mathrm{b}}$ and Cecília de Fátima Souza ${ }^{\mathrm{b}} \odot$
}

\begin{abstract}
BACKGROUND: Brazil is the largest producer of coffee in the world. Studies on climate change estimate large impacts on the production of Coffea arabica ( $C$. arabica). In this context, it is necessary to know the quantitative production values to provide evidence for policy makers to target the prompt answer.

RESULTS: Using data from 18 municipalities located in the five largest coffee producing states in Brazil this work shows although the minimum temperature is the most important climatic variable for the production, its effect, although positive, and its degree of explanation, were technically too small to explain the volume of production in Brazilian conditions. According to the model of non-stationary time series ARIMA $(1,1,0)$ coffee production in the future may reach almost four million tons, and the productivity almost $2500 \mathrm{~kg} \mathrm{ha}^{-1}$ on average, with the advancement of technology as the main factor that should promote simultaneous increases in production and productivity. However, despite natural climate variations, which make it the most responsible for the variability of annual coffee production, the producer must increase the use of the technologies to support the Brazilian coffee agribusiness.
\end{abstract}

CONCLUSIONS: The results of this study reveal that coffee production in Brazil is affected much more by productivity than to the minimum ambient temperature change over the long term; despite this, the climate variable should be considered the most influential on the production and productivity of coffee.

๑) 2017 Embrapa. Journal of the Science of Food and Agriculture $\odot 2019$ Society of Chemical Industry

Keywords: coffee production; yield projections; climate impact; ARIMA model

\section{INTRODUCTION}

Brazil is the largest producer of coffee and the second largest nation in coffee consumption. According to data from Brazilian National Supply Company (CONAB), ${ }^{1}$ Brazil is also the largest exporter of coffee and in 2014 produced 45.3 million processed coffee bags, this being 32.3 million of Arabica and 13 million of Conilon. ${ }^{2}$ The total planted area is mainly located in Minas Gerais, São Paulo and Paraná, where the climate and temperature are ideal for coffee production. In Brazil, propitious areas for coffee rusts will move toward the south, particularly due to the hottest scenario for $2080 .^{3}$ The IPCC Special Report on Managing the Risks of Extreme Events and Disasters to Advance Climate Change Adaptation, ${ }^{4}$ or SREX for short, provides an in-depth assessment of observed and projected changes in climate extremes. It were noted increases of $+0.5^{\circ} \mathrm{C}$ to $+0.6^{\circ} \mathrm{C}$ per decade in the air temperature annual mean in southern Brazil, between the years of 1913 and $2006 .{ }^{5}$ An increase of $10 \%$ to $20 \%$ was observed in the number of warm nights over 41 years in southern Brazil, between 1960 and 2009. ${ }^{6}$ The frequency of heavy rainfall from 50 to $150 \mathrm{~mm}$ was observed in southern Brazil between 1959 and 2002. ${ }^{7}$ The impact of climate variability and change is a great challenge in such a region. ${ }^{8}$ As an example, the recent, 2012-2013, rust problem on the coffee sector has affected nearly 600000 ha $(55 \%$ of the total planted area $)^{9}$ and has reduced employment in the harvest process by $30 \%$ to $40 \%$ in the $2013-2014$ period. ${ }^{10}$ The most recent studies to predict the impact of climate change on coffee production are often based on already existing gradients that correlate the coffee production to climate ${ }^{11}$ (e.g. Gay et al., ${ }^{12}$ Jaramillo et al. ${ }^{13}$ and Jassogne et $a . .^{14}$ ) which 'form the basis of suitability change maps based on downscaled Global Environmental Change (GEC) model projections' (e.g. Mwandosya et al., ${ }^{15}$ Davis et al. ${ }^{16}$ and Läderach et al. ${ }^{17}$ ). Since 2001, crop simulation models, driven by future climate scenarios from global circulation models, suggest that the reduction in crop production would be more severe in the tropical region. ${ }^{18}$ Brazil is located almost entirely in the tropical region, which indicates that the country is susceptible to reductions in crop production. Frequently, coffee producers as well as policy makers are more promptly attentive to short-term problems associated with production and increase in profits, than to those problems mentioned as more relevant by the scientific community. Assessment of the impacts of climate change on the main coffee-producing areas is needed to minimize crop losses facing the future climatic conditions, once a particular environmental

\footnotetext{
Correspondence to: WPM Ferreira, EPAMIG (Empresa de Pesquisa Agropecuária de Minas Gerais), Vila Gianetti, Casa 46, Campus da UFV, Viçosa, MG, Brazil. E-mail:williams.ferreira@embrapa.br

a Embrapa (Brazilian Agricultural Research Corporation) - Research Unit in Coffee, Vila Gianetti, Viçosa, MG, Brazil
}

b Federal University of Vicosa (UFV), Vicosa, Minas Gerais, Brazil 
temperature change may induce different physiological responses in distinct plant species, including coffee, as reported by Batista-Santos et al., ${ }^{19}$ Partelli et al. ${ }^{20}$ and Scotti-Campos et al. ${ }^{21}$ ). In this way, the aim of this work was to assess the potential impact of climate change on the Brazil's Arabica coffee production considering only the effect of air temperature and precipitation as climatic variables, not other crucial factors, such as soil, ${ }^{22,23}$ water, ${ }^{24}$ and altitude, ${ }^{25}$ among others. Thus, it was necessary to identify over the past 52 years (1961-2014), which atmospheric variables had more influence on coffee production in Brazil, as well as to identify at which phenotypic stage the influence of climate was more important and from these conclusions, carry out future projections of climate and yield for 2040 .

\section{EXPERIMENTAL}

In Brazil, Minas Gerais is the biggest producing state and it accounts for over $50 \%$ of the domestic production. The predominant crop in the state is the Arabica coffee. Espirito Santo, the second-biggest producing state, predominantly farms Conilon coffee and it produced almost $80 \%$ of the Brazilian crop of this species. ${ }^{26}$ There are three main coffee Arabica growing areas in Brazil and these plantations are mainly located in the state of Minas Gerais, São Paulo and Paraná where the environment and climate provide ideal growing conditions. ${ }^{27}$ Bahia state is considered the fourth largest producer, with $3.8 \%$ of the estimated production of Arabica coffee in the country in 2014; with the production of 1217.8 thousand bags, being $62.5 \%$ of all this production in traditional areas called 'Planalto' (Fig. 1). ${ }^{28}$

In Brazil, there are about 287000 producers, predominantly small coffee producers, in about 1900 municipalities, ${ }^{29}$ which according to Vilela et $a .^{30}$ are characterized by coffee activity in which their direct relatives perform most of the crop management operations. The total planted area in the country with the coffee crop (Arabica and Conilon) adds up to 2256.5 thousand hectares. ${ }^{26}$ Due its continental dimensions, Brazil has a variety of climates, topography, altitudes and latitudes that allow the production of coffee in a wide area. Considering also that the majority of producers are considered small, this complicates obtaining accurate yield information owing to inaccurate calculations; in addition, there are other problems in Brazil such as those cited by Craparo et al. ${ }^{11}$ in Tanzânia, such as political or economic reasons, illegal trade to other countries/regions, or disinterest in data collection and/or management. Under these circumstances, to minimize bias and error, in this work four data sources of yield and production of coffee were used. The Brazilian data sources include the Brazilian National Food Supply Company (CONAB) (http:// www.conab.gov.br/index.php), the Brazilian Institute of Geography and Statistics (IBGE) (http://www.ibge.gov.br/English), the Institute of Applied Economic Research (IPEA) (http://www.ipea .gov.br/portal/), and the international data source considered was the Agricultural Statistics Division of the Food and Agricultural Organization of the United Nations (FAOSTAT) (http://faostat3.fao .org/faostat-gateway/go/to/home/E) (Fig. 2). The IPEA dataset is the longest series (1900-2013) followed by the FAOSTAT datasets (1961-2013), IBGE dataset (1990-2013) and then the CONAB series (2001 -2013). The data used were annual yield $\left(\mathrm{kg} \mathrm{ha}^{-1}\right)$ and production (1000 t) for the entire country.

\section{Regional climate and data}

Location is a key factor for growing coffee and the site selection is one of the most important choices to ensure success. Coffee plantations in Brazil cover immense areas of land though in different coffee growing regions. The ambient climate, soil quality and altitude largely determine which variety will grow best in which region. Figure 3 presents the climatic types, typical for the major coffee producing regions in Brazil.

Arabica coffee vegetates and fructifies very well at tropical uplands, as in the south-east area of Brazil. It is usually affected in the growth stages by the environmental conditions, especially by photoperiodic variation and by rainfall distribution and air temperature that interfere in the crop phenology, and consequently in the coffee bean yield and quality. ${ }^{32}$ A relatively high air temperature during blossoming, especially if associated with a prolonged dry season, may cause abortion of flowers. ${ }^{33,34}$ Long-term temperature (monthly) and precipitation (daily) data were obtained from the Brazilian National Institute of Meteorology - INMET (http:// www.inmet.gov.br) for the corresponding 53-year period. In order to get the highest climate representation of the Brazilian coffee growing regions, 18 stations were used. These include Machado, Lavras, Caparaó, Viçosa, Divinópolis and Bambuí, in Minas Gerais state; Catanduva, São Carlos, Sorocaba and Presidente Prudente, in São Paulo state; Maringá, Castro and Campos Mourão, in Paraná state; Vitória da Conquista, Canavieiras and Correntina, in Bahia state; and São Mateus and Vitória, in Espírito Santo. Considering the entire phenological cycle of the fructification to the Coffea arabica L. (Arabica coffee trees) ${ }^{35}$ and the C. canephora Pierre ex A. Froehner (varieties 'Conilon' and 'Robusta'), ${ }^{36}$ which are the most marketed in Brazil and worldwide, and given the specific location and corresponding climate of Brazil arabica growing regions, several bioclimatic indices of the phenologically important stages ${ }^{37}$ were calculated and used in the analysis. The variables considered are the mean maximum (TMm), mean minimum (Tmm) and mean (TCm) temperatures for the crop year, which runs from September to August in Brazil. The mean minimum (TminF), mean maximum (TmaxF) and mean (TmeanF) temperatures during the stage of coffee flowering (September-December) and the mean minimum (TminR), mean maximum (TmaxR) and mean (TmeanR) temperatures during the stage of development/ripening (January-June) were also used. Precipitation variable included the total rainfall for the crop year (Pyr), the total rainfall during the flowering period (PF), the total rainfall during the most dry season (Pdry) on the harvest (July-August) and the number of rain days during the short rain season (PDshort) (April-September), the long rain season (PDlong) (October-March) and the flowering period (PDF). Due to the biennial nature of the crop, each precipitation variable was also considered at a lag of 2 years prior to the event. Precipitation anomalies and the standard deviation (SD) were calculated for Pyr and used as a variable.

\section{Statistical analysis}

Initially, graphics were built and some descriptive statistics were obtained related to the coffee production and to the climatic variables, recorded for a period of 53 years, between 1961 and 2013. Pearson's correlation coefficient $(r)$ and its respective significance by the Student $t$ test were applied to determine significant relations among the climatic variables and the crop yield. The considered climatic variables were the minimum environment temperature (Tmm), the average ( $\mathrm{TCm}$ ) and the maximum (TMm), in ${ }^{\circ} \mathrm{C}$, the number of rainy days during the year (PDPr), and the total precipitation for the crop year (Pyr), in $\mathrm{mm}$. The crop yield was given by the coffee production, in 1000 tons (t), and by the coffee yield, in $\mathrm{kg} \mathrm{ha}^{-1}$. In addition, we performed individually linear 


\begin{tabular}{|c|c|}
\hline $55^{\circ} 0^{\prime} 0^{\prime \prime} \mathrm{W}$ & $50^{\circ} 0^{\circ} 0^{\prime \prime W}$ \\
\hline
\end{tabular}

COFFEE PRODUCTION (2014)

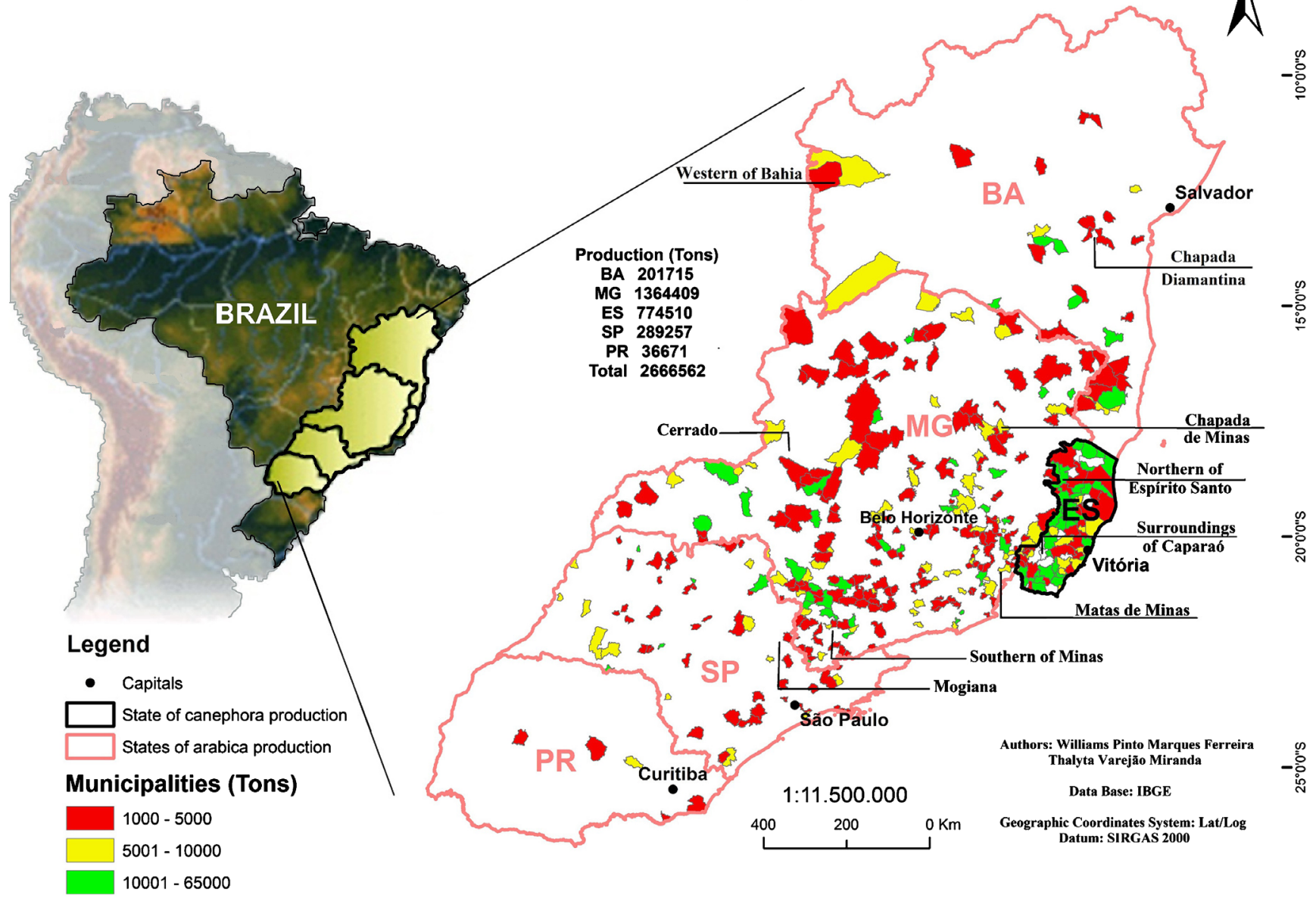

Figure 1. Main coffee producers in Brazil: Bahia - BA; Minas Gerais - MG; Espírito Santo - ES; São Paulo - SP; Paraná - PR. Coffee production 'arabica and canephora' in 2013.

regressions analysis of the production and yield of coffee depending on Tmm. Aiming to verify, if the coffee yield would be a cause for the coffee production, we performed a simple linear regression analysis of the coffee production as a function of coffee yield, for the period of 1961 to 2013. After that, three Autoregressive Integrated Moving Average Model (ARIMA) ( $p, d, q)$ were estimated in accordance to the methodology of Box and Jenkins, ${ }^{38}$ in order to confirm the trends and, or, seasonality, but, mainly to make possible the predictions for after 2013 and until 2060, working with time series of these three variables. The statistical analyses were performed in R software 3.0.3, Minitab 16 and Microsoft Excel 2010, considering the significance probability levels equal to $1 \%$ and $5 \%$.

\section{RESULTS}

The coffee production (in $1000 \mathrm{t}$ ) between 1961 and 2013, ranged from approximately 376 (1976) to 3038 (2012), with an average in this period of almost 1706000 tons. These preliminary results showed an increase in the coffee production of approximately eight times in 53 years of cultivation. However, the coffee yield, in $\mathrm{kg} \mathrm{ha}^{-1}$, ranged from almost 282 (1968) to almost 1433 (2012), with an average of approximately $698 \mathrm{~kg} \mathrm{ha}^{-1}$, which resulted also in a significant increase of close to five times. This generated an amount of 1000 tons more of coffee for each planted hectare.
At the same time in those 53 years, the values for the climatic variables presented variations, as shown in Fig. 4.

As can be seen in Fig. 4, the minimum, average and maximum temperatures, varied randomly from 1961 to approximately 1997 , around of the averages, respectively and approximately by 15, 19 and $25^{\circ} \mathrm{C}$. From the last mentioned year, the frequency values above their averages were concentrated in almost $100 \%$ of the cases. On the other hand, PDPr and Pyr presented cyclic behaviors of classes of values, in subsequent years, above and below the averages 8.3 and 107 respectively. As function of years, the minimum, average and maximum temperatures $\left({ }^{\circ} \mathrm{C}\right)$ showed linear growth trends in approximated and continuous rates of 0.06 , 0.09 and $0.09^{\circ} \mathrm{C}$ per year, respectively (Fig. 5), for which estimated regression equations were given by:

$$
\begin{aligned}
& \mathrm{Tmm}=-113.484+0.064548^{*} \times \text { Year }\left(R^{2}=0.35\right), \\
& \text { to } 1961 \leq \text { Year } \leq 2014
\end{aligned}
$$

$$
\mathrm{TCm}=-127.849+0.073992^{*} \times \text { Year }\left(R^{2}=0.34\right),
$$$$
\text { to } 1961 \leq \text { Year } \leq 2014
$$ 


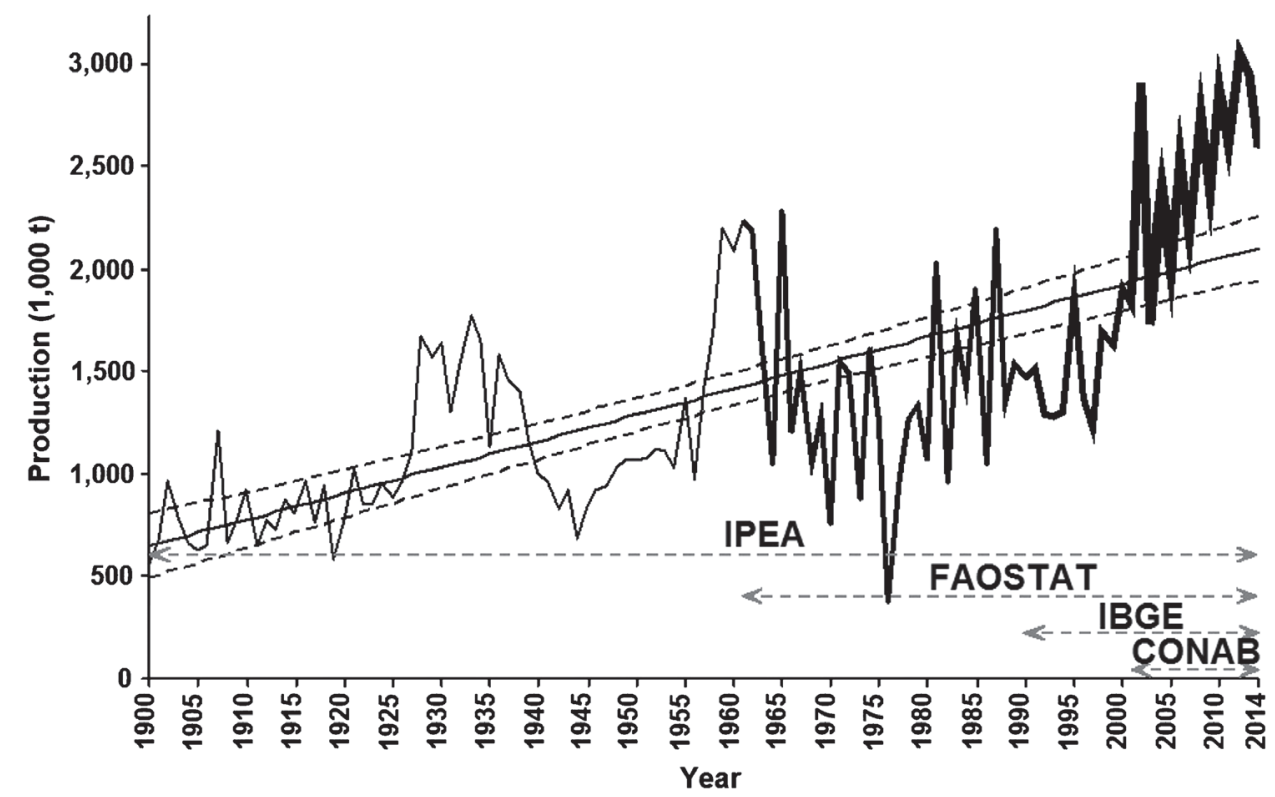

Figure 2. Annual bean arabica production trends for Brazil covering the period from 1900 to 2013 (IPEA), 1961-2013 (FAOSTAT), $1990-2013$ (IBGE) and 2001-2013 (CONAB) of the observed values (continuous lines of different thicknesses) and estimates (straight regression line) with an confidence interval of $95 \%$ fitted to all periods simultaneously, represented by the dashed lines (_ $\left.{ }_{-}\right)$.

$\mathrm{TMm}=-159.565+0.092961^{*} \times$ Year $\left(R^{2}=0.28\right)$,

to $1961 \leq$ Year $\leq 2014$

where $\left(^{*}\right)$ indicates significance at the Student $t$ test $(P<0.05)$.

Based on the results of the temperature trends for the coffee-growing regions of Brazil, in the period of 53 years, it was observed that the tendency of increase in temperature is more slightly driven. This occurs mainly by the increase rate of daily minimum temperature reaching $0.65^{\circ} \mathrm{C}$, on average, per decade $(P=2.89 \mathrm{e}-06)$, when compared with the other, $0.74^{\circ} \mathrm{C}$ to average temperatures $(P=4.12 \mathrm{e}-06)$ and $0.93^{\circ} \mathrm{C}$ to the maximum temperatures ( $P=4.08 \mathrm{e}-05)$ (Fig. 5). On the other hand, PDPr, Pyr and the average relative humidity (Urm) showed no changes of values as a function of the years (Fig. 6), whose estimates were given by: $\operatorname{PDPr}=8.19$, to $1961 \leq$ Year $\leq 2014$; $\mathrm{Pyr}=105.05$, to $1961 \leq$ Year $\leq 2014$ and $U r m=69.86$, to $1961 \leq$ Year $\leq 2014$.

\section{Major climatic phenomena in Brazil and their influence on the climate}

Although some studies indicate that La Niña presents greater variability when compared to El Niño, which display a more consistent pattern, studies for Brazil, like those performed by Coelho et al. $^{39}$ and Grimm ${ }^{40}$ describes the occurrence of abnormalities, mainly in the north-east and south of the country. In a study focused on the south-eastern region of Brazil, Minuzzi et al. ${ }^{41}$ concluded that during La Niña, the rainy season tends to grow in the Mantiqueira region, state of São Paulo. However, in the general context, the climatic phenomena do not influence the beginning of the rainy season in the south-east region of Brazil, while the expressive precipitation anomalies, mainly observed in November-January periods, have no correlations with the behavior of equatorial Pacific Ocean's surface temperature and, or, with the Southern Oscillation Index (SOI). Considering the behavior of atmospheric temperature, this study observes, based on Fig. 7a, that La Niña events contribute with the increase of average air temperature in the coffee-producing region (south-eastern Brazil).
This can be seen in years of moderate-intensity events, such as 1970-1971, 1998-1999 and 1999-2000, considering this increase of the temperature even more evident in those years in which occurred the events considered strong as 1973-1974, 1975-1976 and 1988-1989.

The highest values of air temperature in the south-east were observed in years of El Niño phenomenon occurrence, on moderate intensity $(1963-1964,1987-1988,1991-1992,2002-2003)$ and high intensity (1972-1973, 1982-1983, 1997-1998) (Fig. 7a). Based on Fig. 7b, it can be also observed that in the years of La Niña phenomena incidence, the Pacific Decadal Oscillation (PDO) index presented the pattern of negative (cold phases); however, on PDO positive periods (warm phases), strong El Niño episodes were recorded (1982-1983, 1986-1987, 1992, 1997-1998), when temperatures in south-eastern Brazil were milder. In Fig. 7, this region also presented an average temperature exceeding $20^{\circ} \mathrm{C}$, from the year 2003. Rainfall patterns show large inter-annual variability, with a slight upward trend through the period of 53 years (Fig. 8) for the flowering period (PDF) and for the crop year (Pyr), while there is a slight downward trend for the dry season (Pdry). The rainfall during the crop year (Pyr) increased $8.5 \mathrm{~mm} /$ decade $(P=6.68 \mathrm{e}-01)$. During the dry season (Pdry) there was also a certain balance $(0.98 \mathrm{~mm} /$ decade; $P=9.24 \mathrm{e}-01)$, and an increase of $1.43 \mathrm{~mm} /$ decade $(P=5.94 \mathrm{e}-01)$ during the flowering period (PDF), especially after 1994. These trends are, however, not statistically significant. The trend of anomalies for the crop year (Pyr) also reinforces that above-average rainfalls are occurring more often in several periods, i.e. $50 \%$ of the years had rainfall above the average, being 24\% for the 18-year period between 1964 and 1978, and $20 \%$ for the period of 24 years between 1989 and 2012, whereas in the same years interval (1989-2012) were $24 \%$ below the average and $30 \%$ of all years have had rainfall below the average in the period between 1980 and 1998. Maximum temperatures are also characterized by a larger inter-annual variability, especially during dry season. 


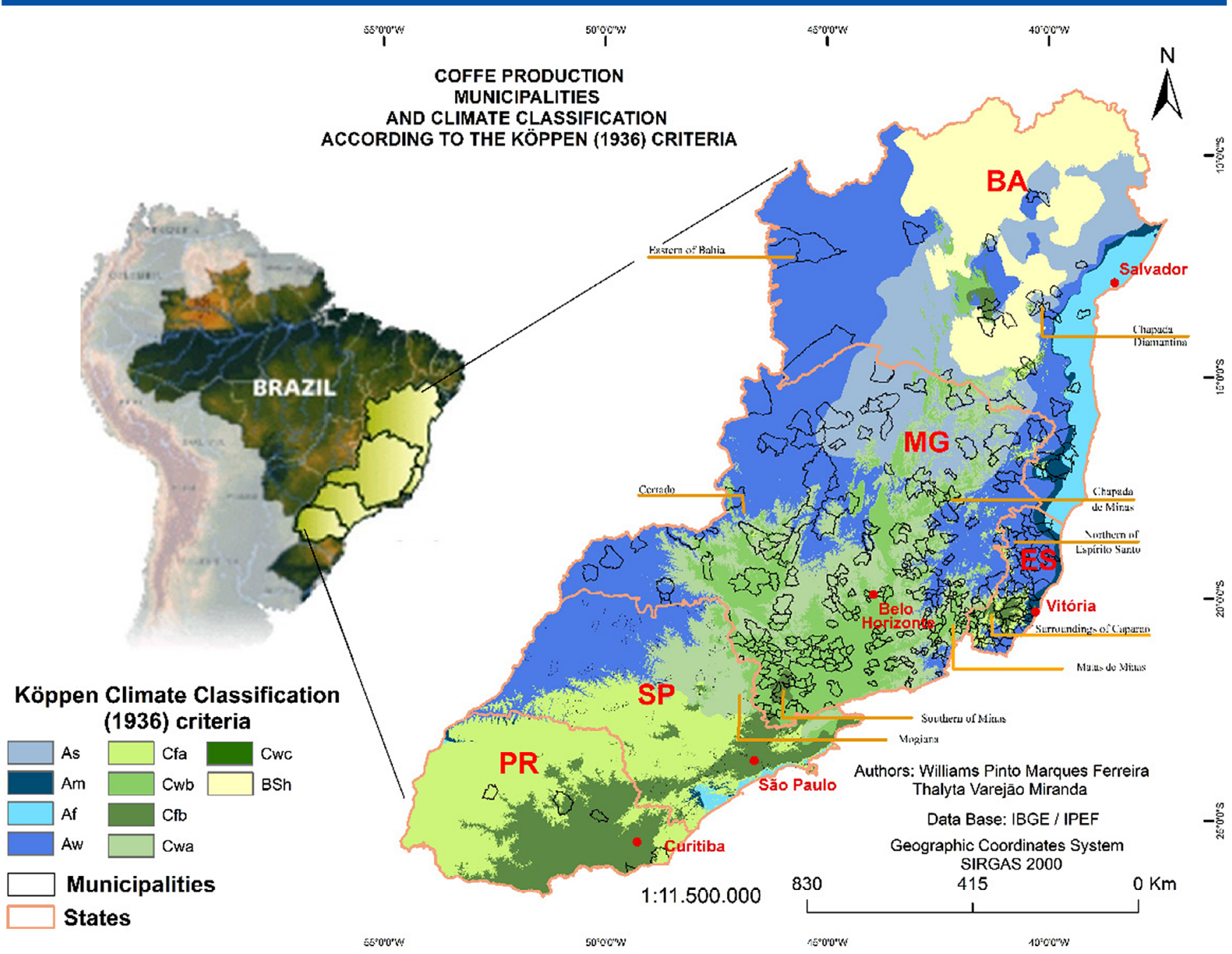

Figure 3. Climate types, typical for the major coffee producing regions in Brazil, adapted from Alvares et al. ${ }^{31}$

\section{Trends in coffee production}

In Brazil, the coffee crisis in production began in fact in 1920, due to continuous, uncontrolled and excessive increase in the coffee harvest that reached amazingly 21 million bags for a world consumption of 22 million. The coffee yields from 1925 to 1926 were big and the 1927-1928 yields were even bigger (a production of approximately 26 million bags), contrary to the trends indicating that after a period of major crops (such as 1925-1926), the crops would decrease. There was a decrease in the period 1928-1929 (14 million bags) and a new increase in 1929-1930 (30 million bags). Between 1956 and 1961 the Brazilian government adopted an interventionist policy for the coffee sector; in 1958 domestic consumption was stimulated by campaigns, and in 1962 the International Coffee Agreement was signed to facilitate the control of production and the pricing in the world market, and all measures culminated in a new record harvest in 1959 which, summed to the stocks of production surplus, culminated with the destruction of 10 million bags between 1959 and 1962 and with the eradication of less productive coffee plantations, aimed at limiting planting and in economic diversification of coffee productions. The international oil crisis of 1970 interfered with the coffee production because it required reordering of investment. ${ }^{43}$ The decade of the 1970s was also marked by the appearance and rapid spread of rust in many crops in Brazil, and it was in this decade the intensification of breeding programs to build resistance against this disease and the reduced-sized coffee selection. However, in 1975, the insurgency of polar air known as 'Polar Outbreaks High' caused a wave of cold, which culminated in a strong frost rain mainly in southern Brazil. However, it also reached the states of São Paulo, Rio de Janeiro and Minas Gerais. The wave of cold reached the equator, with this event responsible not only for the drop in production in the following year but also for the advance of the cultivation's frontier to the 'Cerrado Mineiro' and southern Minas Gerais. At this time, the states of Paraná and São Paulo together corresponded almost $70 \%$ of the national production. In this decade, the Brazilian Coffee Institute (IBC) released funds for a program of renewal and reinvigoration of coffee production. All four productions series (Fig. 2) exhibit the same trends. Smoothing the linear regression line with confidence intervals allows illustrates the strong trend in increasing the coffee production from 1976, being more intense and growing from 1996 when, according to Chalfoun and Reis ${ }^{44}$ the National Program for Research and Development of Coffee (PNP\&D/Coffee) was created, under the responsibility of the Brazilian Agricultural Research Corporation (Embrapa). To manage and run the 'PNP\&D/coffee' the Brazilian Consortium of Research and Development (CBP\&D/Coffee) was created, formed by the Brazilian Agricultural Research Corporation - Coffee Unit and nine other research institutions [Agricultural Development Company 

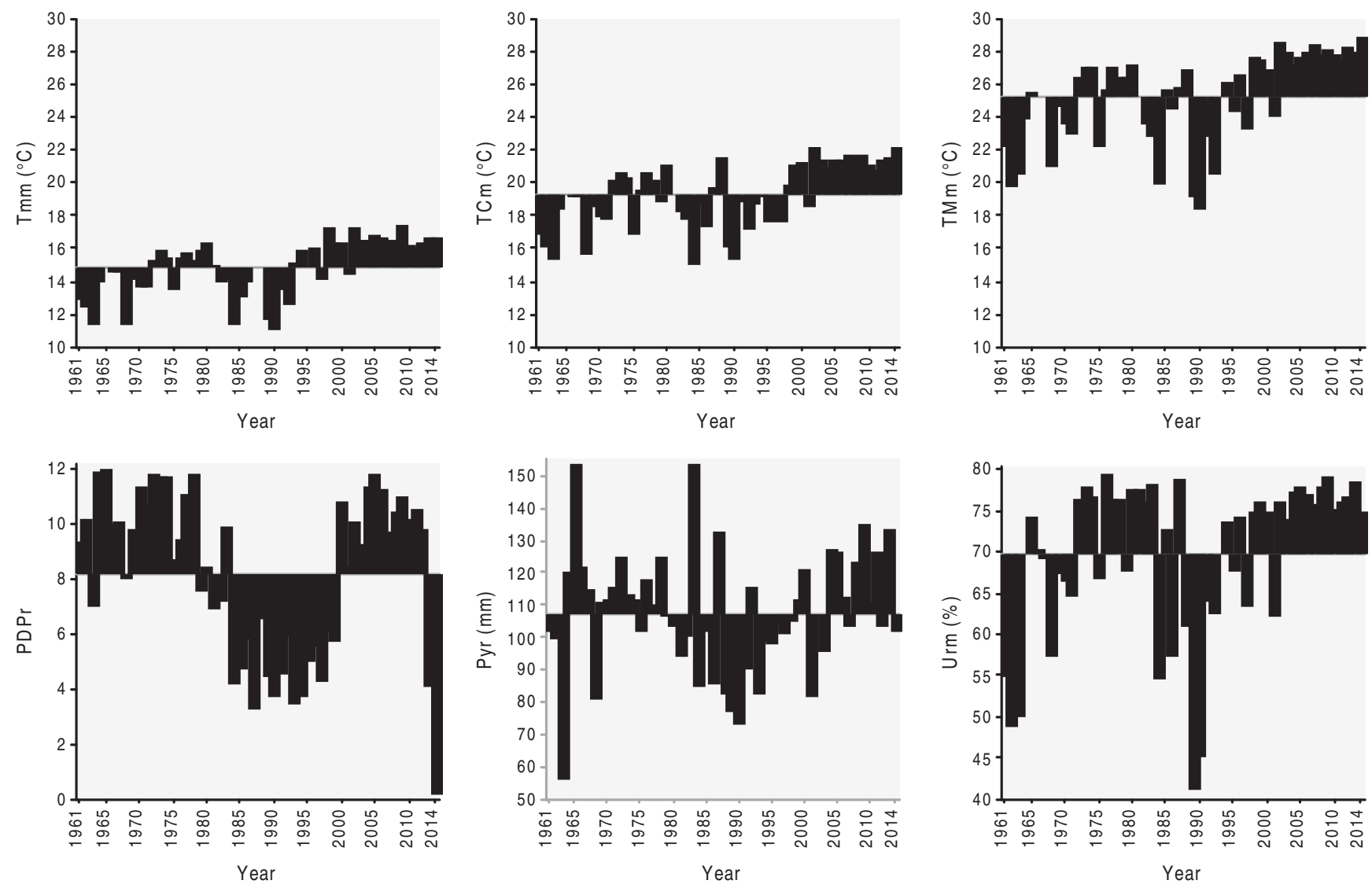

Figure 4. Variations of Tmm, TCm, TMm, PDPr, Pyr and average relative humidity (Urm), from 1961 to 2014, based in data from all considered stations.
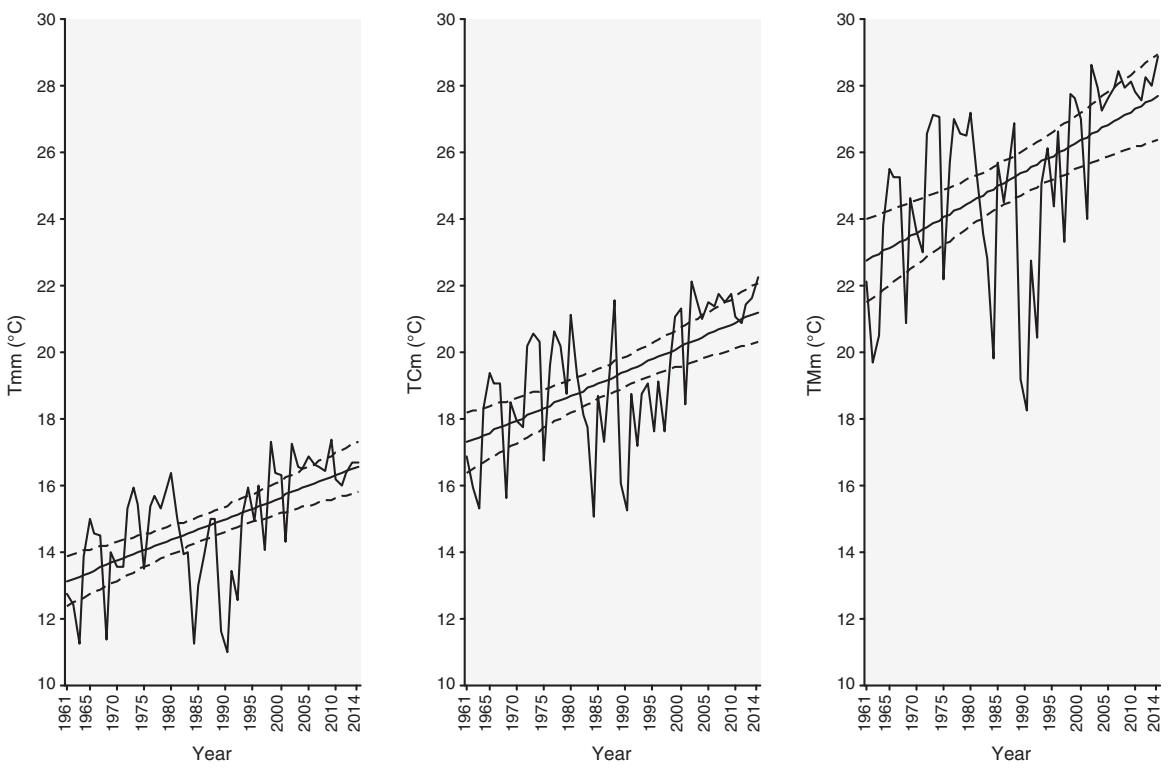

Figure 5. Annual air temperature trends for the 'coffee arabica' growing regions of Brazil. Temperatures are the mean minimum ( $T \mathrm{~mm})$, the average (TCm) and mean maximum (TMm), covering annual averages for the period 1961-2014. The figure presents a series of observed data (continuous lines) and estimates (straight regression line) with a confidence interval of $95 \%$ fitted to each series, represented by the dashed lines (_ _ _).

of Bahia (EBDA), Agricultural Research Company of Minas Gerais (EPAMIG), Agronomical Institute of Campinas (IAC), Agricultural Research Institute of Paraná (IAPAR), Capixaba Research Institute, Technical Assistance, and Rural Extension (INCAPER), Agricultural Research Corporation of the State of Rio de Janeiro (Pesagro),
Ministry of Agriculture, Livestock and Supply (MAPA), Federal University of Vicosa (UFV) and Federal University of Lavras (UFLA)], which in this time has been developing research in partnership with other 40 Brazilian institutions covering 12 coffee-producing states. Representing the greatest experience in the world, related 

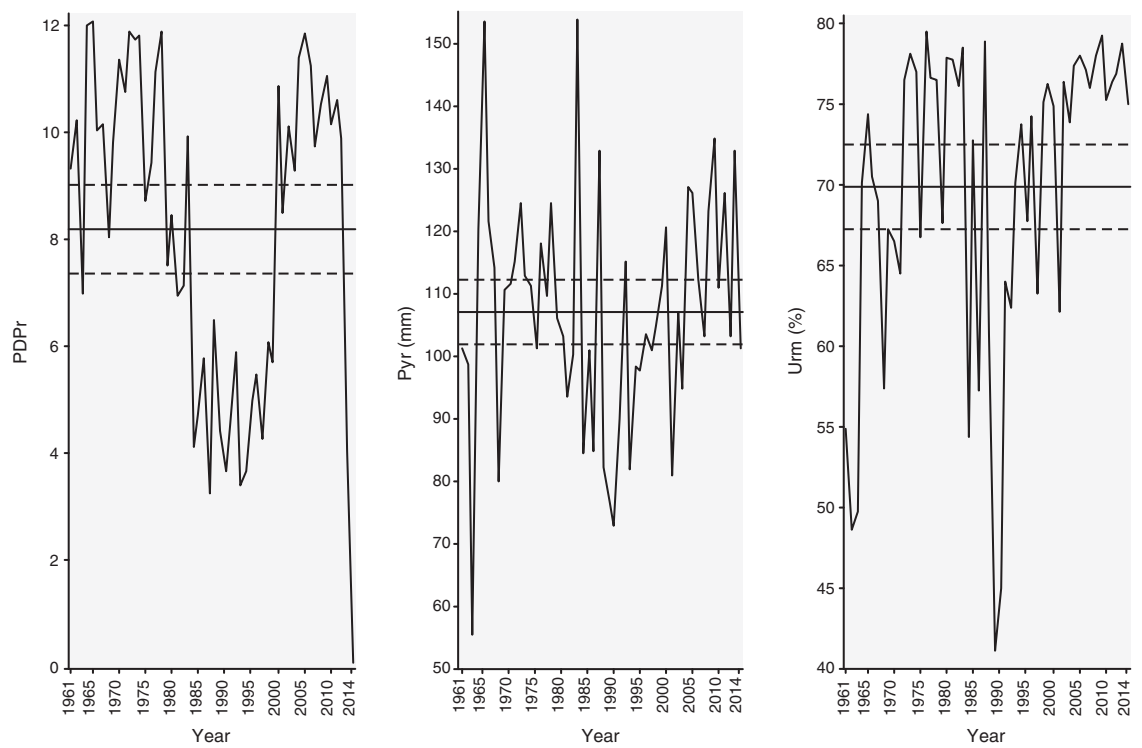

Figure 6. Annual averages trends covering the period from 1961 to 2014 of the observed data (continuous lines) and estimates (straight regression line) of PDPr, Pyr and Urm. A confidence interval of $95 \%$ is fitted to each series, represented by the dashed lines (_ _ _).

Table 1. Estimates of Pearson correlations (dimensionless) between climate variables and coffee production in Brazil

\begin{tabular}{lll} 
Parameter & Pd & Pdt \\
\hline Tmm & $0.41^{* *}$ & $0.62^{* *}$ \\
TCm & $0.46^{* *}$ & $0.66^{* *}$ \\
TMm & $0.40^{* *}$ & $0.61^{* *}$ \\
PDPr & 0.06 & 0.02 \\
Pyr & 0.26 & $0.32^{*}$ \\
Urm & 0.24 & $0.49^{* *}$
\end{tabular}

* Significant at the Student $t$ test $(P<0.05)$; and.

*** significant at the Student $t$ test $(P<0.01)$.

Mean minimum (Tmm), mean (TCm) and mean maximum (TMm) temperatures, in ${ }^{\circ} \mathrm{C}$; number of rainy days during the year (PDPr), in days; total rainfall for the crop year (Pyr), in $\mathrm{mm}$; average relative humidity (Urm), in \%; production (Pd), in 1000 tons, and yield (Pdt), in $\mathrm{kg} \mathrm{ha}^{-1}$.

to the number of institutions and researchers around a single product, Brazil guarantees its current position as the world's largest coffee producer, responsible for $30 \%$ of the international coffee market, volume equivalent to the total production of other six largest producing countries.

\section{Crop-climate interaction and forecast estimations}

The production $(\mathrm{Pd})$, in 1000 tons, and the yield of coffee (Pdt), in $\mathrm{kg} \mathrm{ha}^{-1}$, were more related to the temperatures in ${ }^{\circ} \mathrm{C}(\mathrm{Tmm}, \mathrm{TCm}$ and TMm), according to the estimates of correlations (Table 1). Due to the Tmm, the linear regressions obtained by Stepwise method, as well as the $95 \%$ confidence intervals for the averages of $\mathrm{Pd}$ and Pdt (Fig. 9), is given by:

$$
\begin{aligned}
& \mathrm{Pd}=-462.191+147.4013^{*} \times \mathrm{Tmm}\left(R^{2}=0.17\right), \\
& \text { to } 10.92 \leq \mathrm{Tmm} \leq 17.33
\end{aligned}
$$

$$
\begin{aligned}
& \text { Pdt }=-909.837+109.4954^{*} \times \operatorname{Tmm}\left(R^{2}=0.38\right), \\
& \text { to } 10.92 \leq \mathrm{Tmm} \leq 17.33
\end{aligned}
$$

where $(*)$ indicates significance at the Student $t$ test $(P<0.05)$.

Although the Tmm has been considered the most important climate variable that has the most impact on the production and the yield of coffee, it was concluded that its effect, although positive, and its degree of explanation, were technically very small. Therefore, related to coffee production as a function of coffee yield, which showed significant increases in recent years due to improved technology and to the interference of the results of researches about coffee. In this case, it was concluded that, in Brazil, the coffee production (1000t) was many due the coffee yield $\left(\mathrm{kg} \mathrm{ha}^{-1}\right)$, as analyzed by a linear relationship and visualized by estimates of the regression equation and the range with $95 \%$ confidence for the average (Fig. 10):

$$
\begin{aligned}
& \mathrm{Pd}=439.8192+1.800109^{*} \times \mathrm{Pdt}\left(R^{2}=0.78\right) \\
& \text {, to } 281.91 \leq \mathrm{Pdt} \leq 1432.75
\end{aligned}
$$

where $(*)$ indicates significance at the Student $t$ test $(P<0.05)$.

As can be seen in Fig. 10, the linear dependence of the production was stronger and more evident only for the highest yield rates (above $800 \mathrm{~kg} \mathrm{ha}^{-1}$ ), revealing that higher demands in the volume of coffee production to attend the greater demand for domestic consumption and exportation, will only be achieved from more technically qualified plantations. In addition, the variation in the coffee production associated to the coffee yield and not to the Tmm, was reinforced by the estimate of the autoregressive time series model of first-order with mean and variance stationary that therefore considered the trend as a function of the time, which was previously estimated as random. Thus, the minimum temperatures observed between 1961 and 2013 only depended on themselves, because of a lag, but still without sufficient information to consider them as originating from a related time series, in Brazil, to the global warming. 
(a)

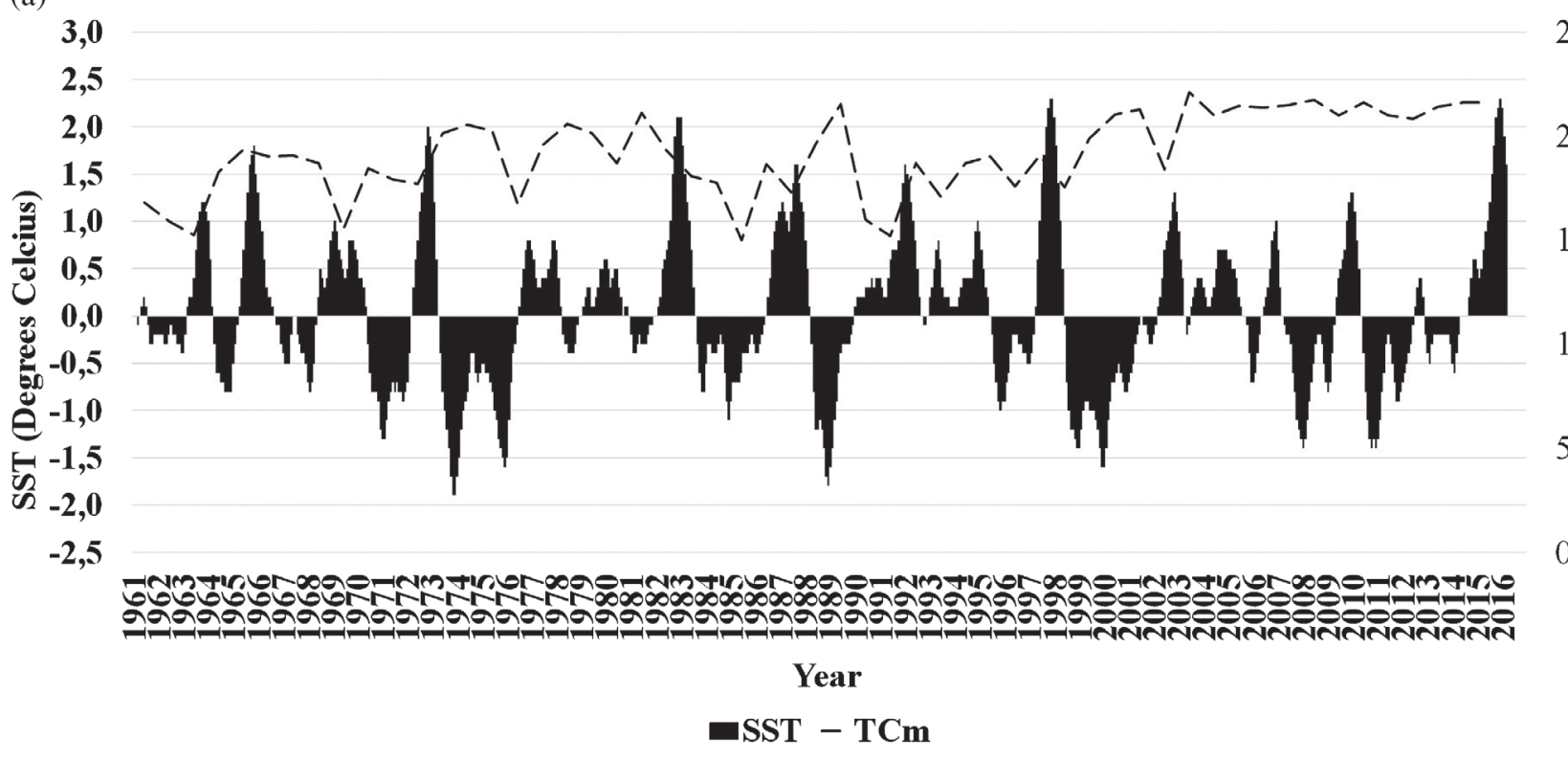

0

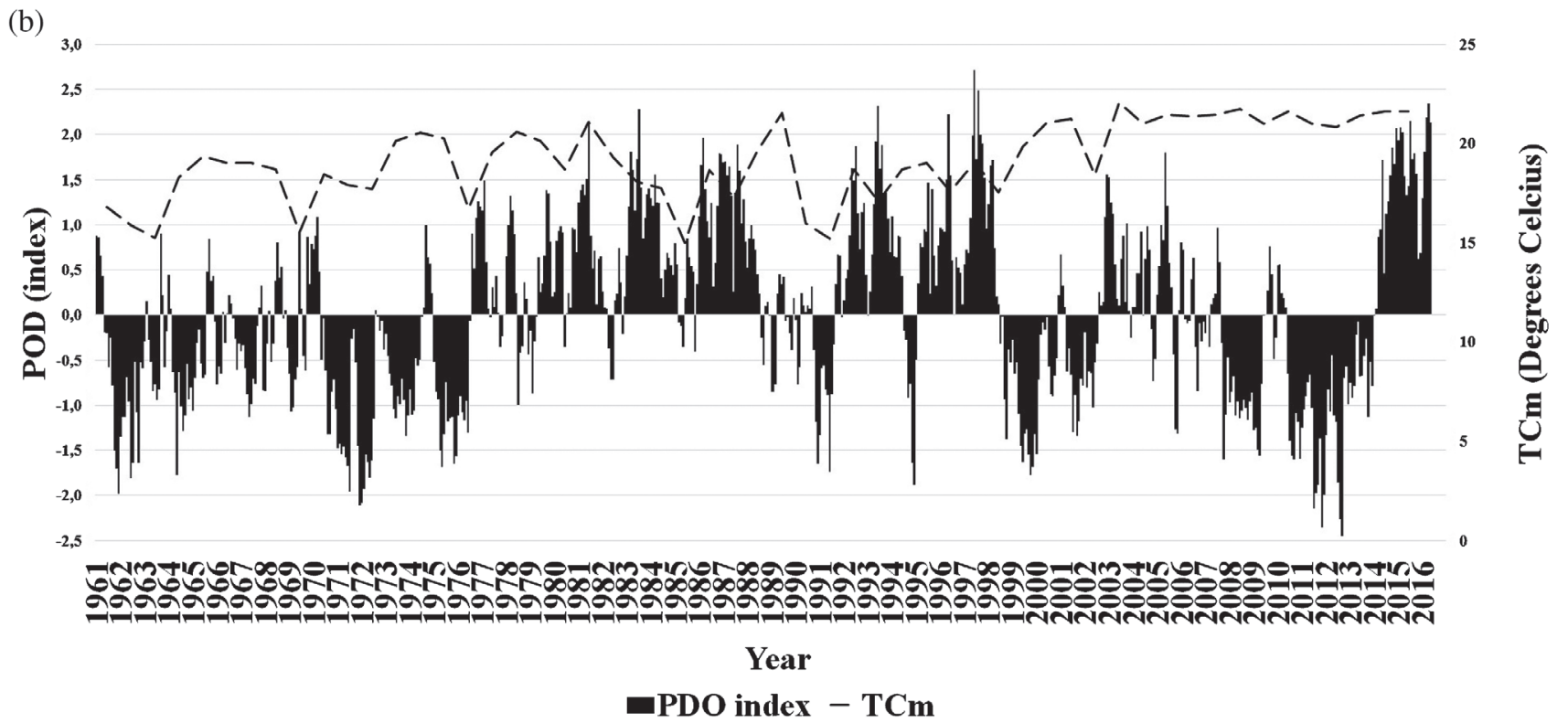

Figure 7. (a) The Oceanic Niño Index (ONI), which is one measure of the El Niño-Southern Oscillation based on SST anomalies averaged across a given region of the Pacifc Ocean, and the environment average temperature (TCm). (b) Pacific Decadal Oscillation, which is often described as a long-lived El Niño-like pattern of Pacific climate variability. ${ }^{42}$ Prepared by http://ggweather.com/enso/oni.htm based on historical data of http://www.cpc.noaa.gov/ products/analysis_monitoring/ensostuff/ensoyears.shtml .

\section{DISCUSSION}

\section{Context and implications}

The results in this study suggest that despite having observed a discrete increase in maximum, average and minimum temperatures, the increase in Brazil's crop production in recent years is strongly correlated with the increase in crop yield in recent years, due mainly to the adoption of new technologies. This result differs from that found by Craparo et al., ${ }^{11}$ according to which, the temperature of the air, as climatic element, had the highest correlation with the coffee production, with the increase mainly in the minimum temperature, resulting in a significant loss of income.

The absence of direct influence of minimum temperature on Brazil's coffee production, which according to Craparo et al., ${ }^{11}$ was the most determinant factor for the yield and production of coffee in Tanzânia, is ratified on the basis of the future predictability provided by the $95 \%$ confidence level with a range estimated by the ARIMA model $(1,1,0)$ in which the average rise of Tmm was too small and with low reliability (Fig. 11).

Despite a non-stationary series adjustment, and with the tendency of increase in the average value of Tmm due to the observed values between 1961 and 2014, whose extrapolation until the year of 2040 implies an average for the $\mathrm{Tmm}$ of $18.63^{\circ} \mathrm{C}$, at an average rate of $0.0698^{\circ} \mathrm{C}$ per year, the generated projections are still not very informative and sufficient to consider the minimum temperatures as originated from a time series related, here in Brazil, with global warming. 

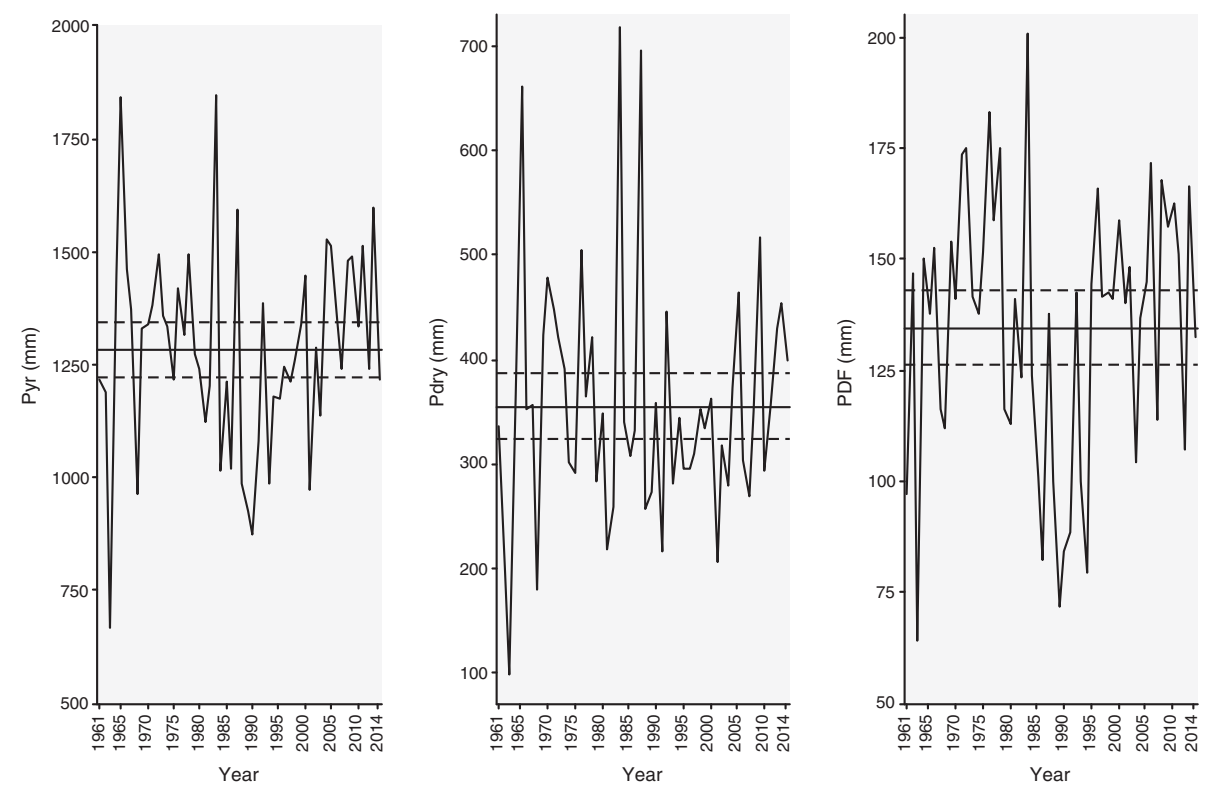

Figure 8. Annual averages trends covering the period from 1961 to 2014 of the observed data (continuous lines) and estimated precipitation (straight regression line), for the coffee-producing regions in the states of Minas Gerais, Espírito Santo, Bahia, Paraná and São Paulo, in Brazil. A confidence interval of $95 \%$ is fitted to each series, represented by the dashed lines (___ _. The trends represent the anomalies of Pyr for the crop year (September-August), anomalies for the dry season (Pdry) (April-September) and anomalies for the flowering period (PDF) (September-December).
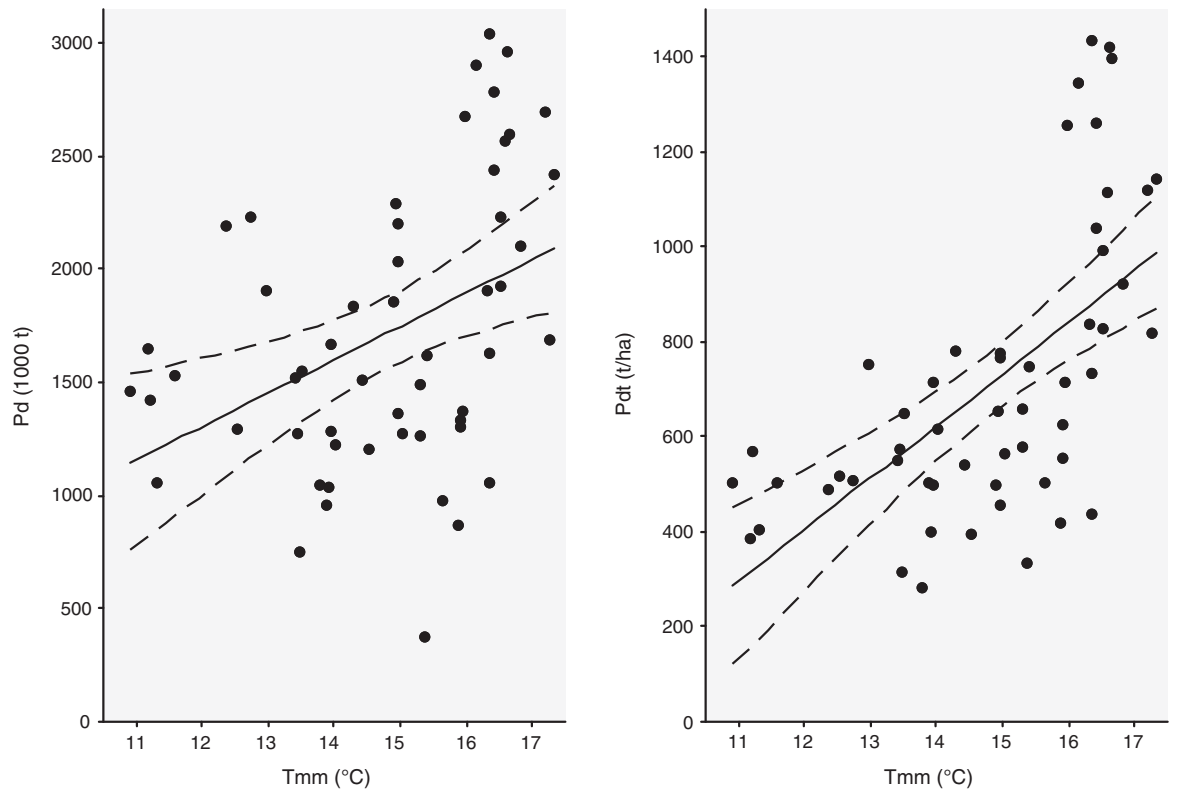

Figure 9. Observed values of Pd (production) and Pdt (yield), represented by points ( $\bullet$ ), respective estimates as a function of Tmm (mean minimum air temperature), represented by the linear regression line (__ $)$ and, confidence interval of $95 \%$ fitted to each series, represented by the dashed lines (_ _-_).

This conclusion is related to the future predictability provided by the confidence interval estimated by the ARIMA model $(1,1,0)$, which, inevitably, does not exclude the possibility of no change or exist a negative tendency for the Tmm. According to the results, in 2040, the Tmm can reach an average between 7.84 and $29.42^{\circ} \mathrm{C}$ (Fig. 11).

It is observed in Fig. 11 that the simulated results of Tmm by the ARIMA model between 1961 and 2015 were very close, when compared with the real data registered by the sensors, allowing to assure the validity of the ARIMA model.

The tendency of the average increase of Tmm was also estimated previously but, likewise, with a low explanation $\left(R^{2}=0.35\right)$ by the linear regression model, which average rate of estimated increase per year was of $0.0645^{\circ} \mathrm{C}$ (Fig. 5).

The reason for the average increases of the $\mathrm{Pd}$ of $147400 \mathrm{t} \mathrm{per}{ }^{\circ} \mathrm{C}$ $\left(R^{2}=0.17\right)$ and of Pdt to $109.5 \mathrm{~kg} \mathrm{ha}^{-1}$ per ${ }^{\circ} \mathrm{C}\left(R^{2}=0.38\right)$ are poorly explained by Tmm (1961 to 2014) and is because this temperature has not yet been manifested, temporally, in better defined relationships and governed by climate change (Figs 9 and 12).

These results make it impossible, technically, to infer, even if they are presented as satisfactory for the coffee production, that the increase of Tmm will benefit them. Therefore, it is believed that most of the explanations about the increase of Pd and the Pdt depending on the years, come from other factors. Among the 


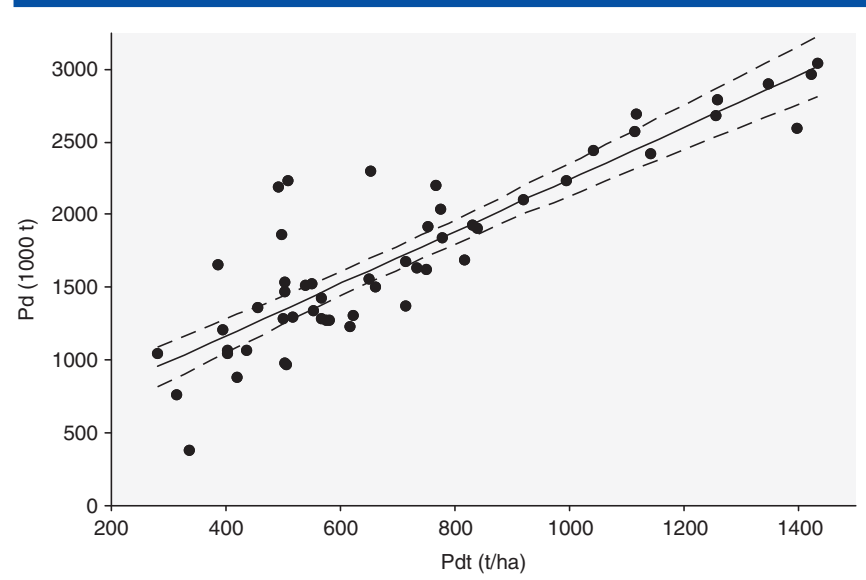

Figure 10. Observed values of Pd (production) represented by points ( $\bullet$ ), respective estimates as a function of Pdt (yield), represented by the linear regression line (__ ) and, confidence interval of $95 \%$ fitted to each series, represented by the dashed lines (_ _ $)$.

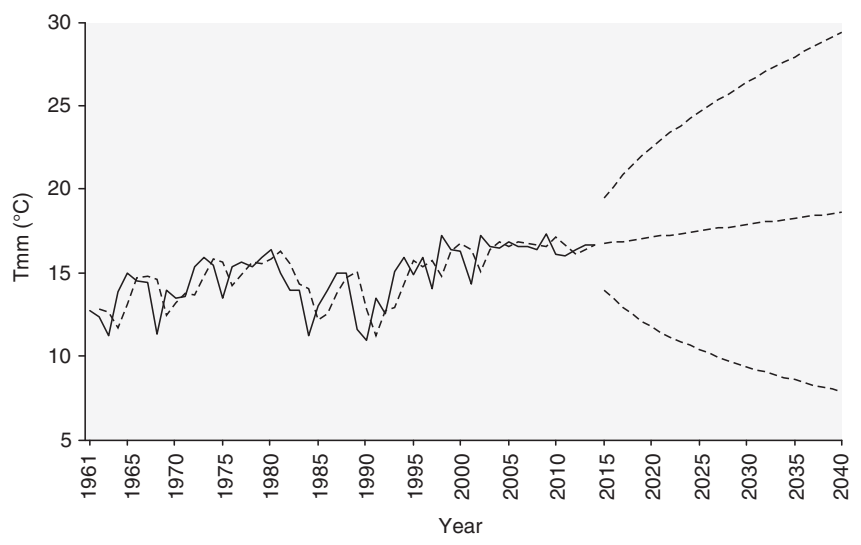

Figure 11. Annual averages trends, covering the period from 1961 to 2014, of the observed (___ ) and estimated (__ _ ) value of Tmm (mean minimum air temperature, and the forecasted values according to the ARIMA model $(1,1,0)$, represented by the dashed straight line from 2015 to 2040 with an associated confidence interval of $95 \%$.

other factors related to the increase of $\mathrm{Pd}$, it was concluded that Pdt is very directly related $\left(R^{2}=0.78\right)$, giving a medium increase of $1800 \mathrm{t}$ for each increase of $1 \mathrm{~kg} \mathrm{ha}^{-1}$ (Fig. 10):

$$
\begin{gathered}
\mathrm{Pd}=1411.993, \text { to } 1961 \leq \text { Year }<1994.04 \\
\mathrm{Pd}=-156909+79.3971^{*} \times \text { Year, } \\
\text { to } 1994.04 \leq \text { Year } \leq 2014\left(R^{2}=0.62\right) \\
\mathrm{Pdt}=530.5764, \text { to } 1961 \leq \text { Year }<1993.46 \\
\mathrm{Pdt}=-87262+44.0403^{*} \times \text { Year, } \\
\text { to } 1993.46 \leq \text { Year } \leq 2014\left(R^{2}=0.86\right)
\end{gathered}
$$

where $(*)$ indicates significance by the Student $t$ test $(P<0.05)$.

Therefore, the advance of technology was the main factor promoting the simultaneous increases in production and yield of the coffee, whose future trends of growth for both variables were also confirmed by the estimates of the intervals with $95 \%$ confidence for the averages, by means of the models the non-stationary time series ARIMA $(1,1,0)$ (Fig. 13). According to these models, the future prospects for Brazil are very good, with it possible for the production of coffee to reach nearly three million tons, and the yield of coffee nearly $1900 \mathrm{~kg} \mathrm{ha}^{-1}$ on average.

Based on the results shown in Fig. 13, the simulated values according to the ARIMA model $(1,1,0)$ between the years 1961 and 2015, for Pd and Pdt, presented similar behavior to those of the real data, thus making the model suitable for the projection of the scenario of these important measures of agronomic performance.

\section{Outlook (perspective)}

The agri-climatic relationships described in this work represent the main regions for cultivation of $C$. arabica and $C$. canephora in Brazil, those which face climate change scenarios because, according to Marengo and Camargo, ${ }^{45}$ in the south-east region of Brazil, where there is the largest coffee producing region in the world, the minimum temperature increased $0.8^{\circ} \mathrm{C}$ per decade in the last six decades, which is more than twice the rate of change for the maximum temperature. ${ }^{46}$ Another aspect is that the largest coffee-producing regions of the state of Minas Gerais, which is the largest state producer of Arabica coffee in Brazil, are located in areas with mountainous land which, according to Quintana-Gomez ${ }^{47}$ and Vuille et al. ${ }^{48}$ are the places where the minimum temperature increase trends are becoming more prevalent. In the African continent, studies like the one performed by Craparo et al. ${ }^{11}$ show that climate change is already impacting the Arabica coffee. Sector in the East African Highlands region. Other studies focusing on the African highlands have also reported increasing in the minimum temperatures (e.g. New et al. ${ }^{49}$ Omondi et al. ${ }^{50}$ ). In Brazil $^{51}$ report records of $112 \%$ increase in coffee production during the period 1996-2010, mainly due to the intensification of robusta coffee production. According to National Food Supply Company, ${ }^{52}$ the robusta coffee production represented $25.9 \%$ and Arabica $74.1 \%$ of the national production. Such numbers are due in part to greater tolerance of Coffea canephora (robusta) to the climate variability that is the factor that most affects the annual production. When it comes to climate variability in Brazil, the El Niño-Southern Oscillation (ENSO), according to McPhaden et al. ${ }^{53}$ is the major climatic phenomena that regionally influences on country tropical variability and substantially affects human and natural systems. According to (WGI AR5 Sections 14.4, 14.8), although projections models indicate that ENSO remains to be in the future the main responsible for the climate variability of tropical regions, where the most of the Brazil area is placed, there is little evidence to indicate that the current climate change resulting from the atmospheric warming forced by GHG warming will cause changes in the natural modulation of ENSO occurrences.

\section{CONCLUSION}

From the use of different statistical analysis in this study, it was concluded that although the minimum temperature is the most important climatic variable for the crop production, its effect, although positive, and its degree of explanation, were technically too small to explain the volume of crop production in Brazilian conditions. When the crop production was related in terms of crop yield, the results showed significant increases in recent years due to modern technology adoption and improvement in the management, based on the results of research on coffee from different institutions involved in research, teaching and extension that participate in the Brazilian Consortium of Research and Development 

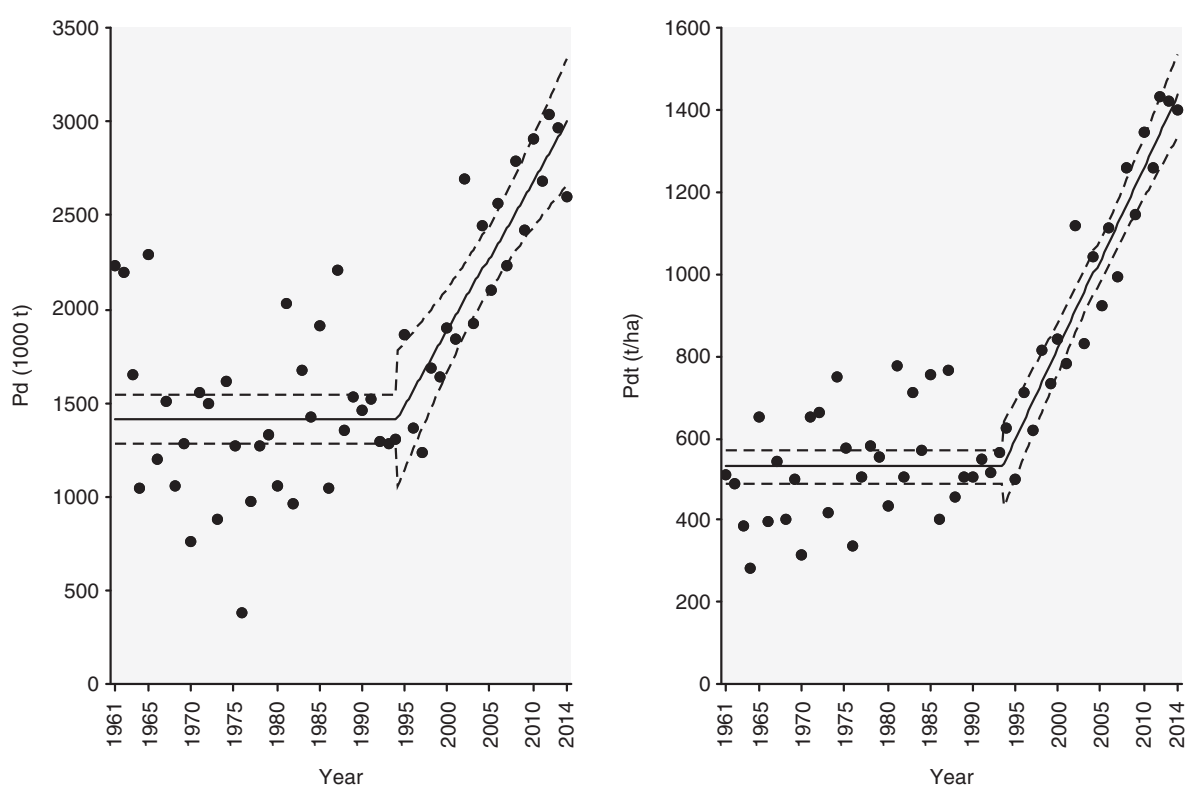

Figure 12. Annual averages trends, covering the period from 1961 to 2014, of the observed values of Pd (production) and Pdt (yield), represented by points $(\bullet)$, respective estimates, represented by the linear regression line (_) and, confidence interval of $95 \%$ fitted to each series, represented by the dashed lines (__- ).
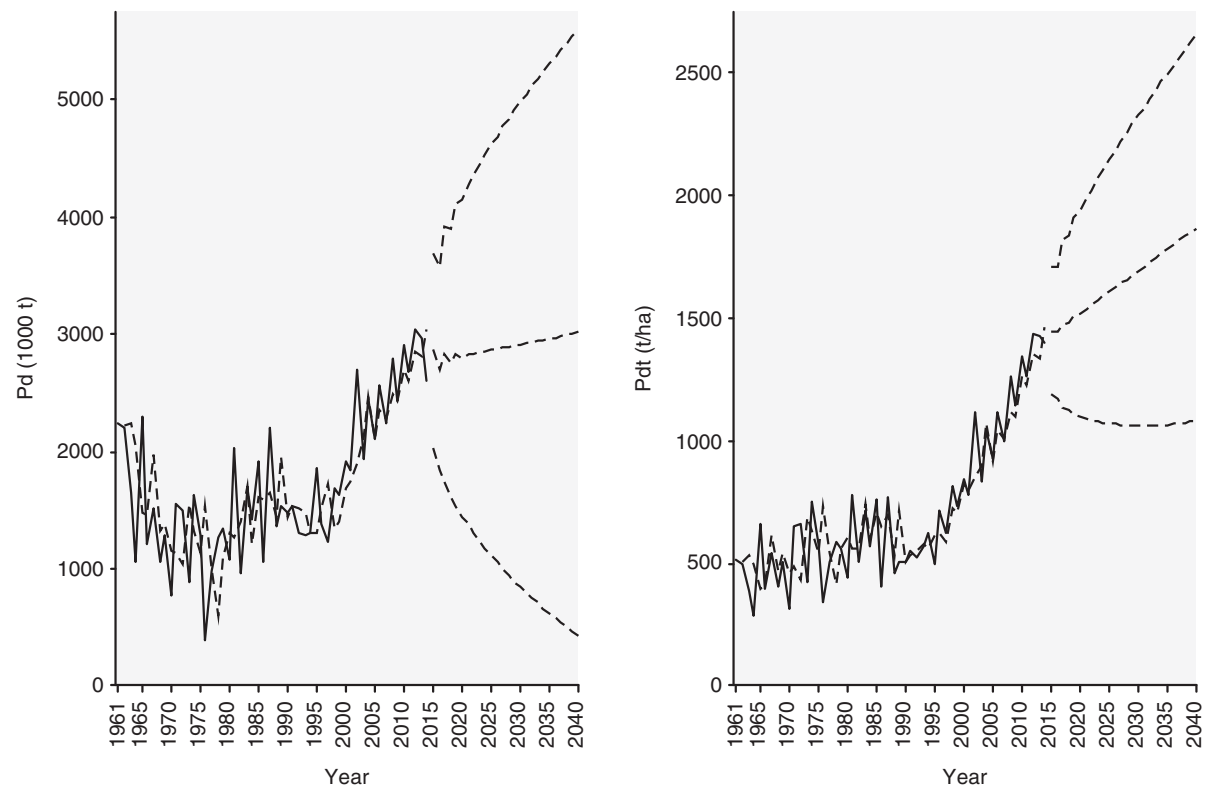

Figure 13. Annual averages trends, covering the period from 1961 to 2014, of the observed (__ _ ) and estimated (___ ) values of Pd (production) and Pdt (yield), and respective forecasted values according to the ARIMA model $(1,1,0)$, represented by the dashed straight lines with an associated confidence interval of $95 \%$.

of Coffee-CBP\&D/Coffee. Also, it can be concluded that coffee production at higher levels (yield up to $800 \mathrm{~kg} \mathrm{ha}^{-1}$ ), able to withstand the greater demands of consumption and exports will only be achieved from more technically qualified plantations. Considering the $95 \%$ reliability interval for ' $\mathrm{Tmm}^{\prime}$ (Fig. 11 ), ' $\mathrm{Pd}$ and $\mathrm{Pdt}$ (Fig. 13), during the studied period, it was noted that when compared to the observed data, the values simulated by the ARIMA model $(1,1,0)$ can be considered representative of the variability of the considered parameters, thus ensuring the validity of the model. The forecast made in this study for the future trend of minimum temperature with the $95 \%$ confidence interval, estimated by the ARIMA model, indicates for coffee-growing regions, little variability in this meteorological element, for which the average value will stands on around $16^{\circ} \mathrm{C}$. That result is the basis to justify that, in Brazil, coffee production does not depend on the 'Tmm'. The results of the models of non-stationary time series ARIMA (1, 1, $0)$, reveal that coffee production in the future may reach over three million tons a year, and the yield almost $1900 \mathrm{~kg} \mathrm{ha}^{-1}$, on average, because the advance of agricultural technology stands out as the main factor that should promote the simultaneous increases in yield and production of coffee. The climate of Brazil, with its vast territorial extension, stands out as the main factor responsible for the extensive range suitable for the production of coffee, which is grown from latitude $0^{\circ}$ in the far north of the country, to 
the latitude $25^{\circ}$, in the south-east of Brazil, i.e. cultivation occurs in different climatic zones, inducing producers to adopt different management strategies in different regions of Brazil, enabling the production of coffee with its own characteristics, specific to each place. So, in addition to the concern about the volume of production, in Brazil there is, today, a very large concern with the regionalization in the production of coffee, i.e. the quality of coffee is associated with both the historical tradition of the production of a peculiar region, including human factors (processes and adopted technologies), as the geographical features of the city, region or locality where it is produced. Thus, this group or factors expresses the specific terroir of each Brazilian region, which is the combined effect of soil, slope orientation in relation to the sun, altitude, climate characteristics like rain, wind speed, accumulated hours of sunshine, minimum temperature, maximum and average, which able to act on the nature and quality of the products grown on this location. In fact, the natural climate variations are considered the main factors responsible for the variability of annual coffee production forcing Brazilian producers to increasingly adopt technologies capable of reducing the impact of climate influence on the yield of coffee. The climate is also the main factor responsible for the product supply imbalance in the international market, causing a constant annual variation in the price quotation. However, despite this, the producer must each day increase the technological support to the Brazilian coffee agri-business since the results of this study reveal that coffee production in Brazil is much more due to crop yield than to the change in the minimum ambient temperature over the long term, in spite of this climate variable be considered the most influential on the production and yield of coffee.

\section{ACKNOWLEDGEMENTS}

This research received a grant from Programa Café 02/2013, number 02.13.02.005.00.00. The research reflects the effort and dedication of the researchers involved, who would like to thank: Brazilian Coffee Consortium, CBP\&D/Research and Development of Coffee, Brazilian Agricultural Research Corporation (EMBRAPA), Coffee Research Unit, Agricultural Research Company of Minas Gerais (EPAMIG), Departments of Statistics and Agricultural Engineering of Federal University of Vicosa for logistical support. We are grateful to the Brazilian National Institute of Meteorology (INMET) for providing the climate data; and to the Institute for Applied Economic Research (IPEA), Statistics Division of FAO (FAOSTAT), Brazilian Institute of Geography and Statistics (IBGE) and National Food Supply Agency (CONAB) for kindly providing data of coffee production.

\section{REFERENCES}

1 CONAB (National Food Supply Company), Follow up of the Brazilian Crop: Coffee, Season 2015, First Assessment, vol. 1. CONAB, Brasília, pp. 1-43 (2014).

2 Instituto de Pesquisa Econômica Aplicada, Macroeconomico/Séries Históricas/Produção-café-qtde. IPEA (2015). Available: http://www .ipeadata.gov.br/ [02 July 2016].

3 Alves MDC, de Carvalho LG, Pozza EA, Sanches L, Maia JC de S, Ecological zoning of soybean rust, coffee rust and banana black Sigatoka based on Brazilian climate changes. Earth System Science 2010: Global Change, Climate and People 6:35-49 (2011).

4 Intergovernmental Panel on Climate Change (IPCC), Managing the Risks of Extreme Events and Disasters to Advance Climate Change Adaptation. A Special Report of Working Groups I and II of the IPCC, ed. by Field CB, Barros V, Stocker TF, Qin D, Dokken DJ, Ebi KL et al. Cambridge University Press, Cambridge, UK and New York (2012).

5 Sansigolo CA and Kayano MT, Trends of seasonal maximum and minimum temperatures and precipitation in southern Brazil for the 1913-2006 period. Theor App. Climatol 101:209-216 (2010).

6 Rusticucci M, Observed and simulated variability of extreme temperature events over South America. Atmos Res 106:1 - 17 (2012).

7 Re M and Barros V, Extreme rainfalls in SE South America. Clim Change 96:119-136 (2009).

8 Intergovernmental Panel on Climate Change (IPCC), Climate Change 2014: Impacts, Adaptation, and Vulnerability. Part B: Regional Aspects. Contribution of Working Group II to the Fifth Assessment Report of the Intergovernmental Panel on Climate Change, ed. by Barros VR, Field CB, Dokken DJ, Mastrandrea MD, Mach KJ, Bilir TE et al. Cambridge University Press, Cambridge, UK and New York (2014).

9 International Coffee Organization (ICO), Report on the Outbreak of Coffee Leaf Rust in Central America and Action Plan to Combat the Pest, ED 2157/13. ICO, London (2013).

10 Famine Early Warning Systems Network (FEWS NET), Special Report Central America: Coffee Sector Shocks and Projected Food Security Impacts in Central America. FEWS NET, Washington (2013).

11 Craparo ACW, Van Asten PJA, Läderach P, Jassogne LTP, Grab SW, Coffea arabica yields decline in Tanzania due to climate change: Global implications. Agric Meteorol 207:1 - 10 (2015).

12 Gay C, Estrada F, Conde C, Eakin H and Villers L, Potential impacts of climate change on agriculture: a case of study of coffee production in veracruz, mexico. Clim Change 79:259-288 (2006).

13 Jaramillo J, Muchugu E, Vega FE, Davis A, Borgemeister C and Chabi-Olaye A, Some like it hot: the influence and implications of climate change on coffee berry borer (Hypothenemus hampei) and coffee production in East Africa. PLoS One 6:1 - 14 (2011).

14 Jassogne L, Läderach P and Van Asten P, The Impact of Climate Change on Coffee in Uganda: Lessons From a Case Study in the Rwenzori Mountains. Oxfam Research Reports. Climate Change and Resilience, Oxford, UK, pp. $51-66$ (2013).

15 Mwandosya MJ, Nyenzi BS and Lubanga, ML, The Assessment of Vulnerability and Adaptation to Climate Change Impacts in Tanzania, CEEST Book Series vol. 11. Dar es Salaam, Tanzania, p. 256 (1998).

16 Davis AP, Gole TW, Baena S and Moat J, The impact of climate change on indigenous arabica coffee (Coffea arabica): predicting future trends and identifying priorities. PLoS One 7:1 - 13 (2015).

17 Läderach P, Eitzinger A, Ovalle O and Carmona Rahn SE, Brief: Future Climate Scenarios for Tanzania's Arabica Coffee Growing Areas. Centro Internacional de Agricultura Tropical, Cali, Colômbia (2012).

18 Intergovernmental Panel on Climate Change (IPCC), Climate Change: Impacts, adaptation \& vulnerability. Contribution of Working Group II to the Third Assessment Report of the IPCC, ed. by McCarthy J, Canziani OF, Leary N, Dockken D and White KS. Cambridge: University Press, Cambridge, UK (2001).

19 Batista-Santos P, Lidon FC, Fortunato A, Leitão AE, Lopes E, Partelli FL et al., The impact of cold on photosynthesis in genotypes of Coffea spp. - photosystem sensitivity, photoprotective mechanisms and gene expression. J Plant Physiol 168:792-806 (2011).

20 Partelli FL, Batista-Santos P, Scotti-Campos P, Pais IP, Quartin VL, Vieira HD et al. Characterization of the main lipid components of chloroplast membranes and cold induced changes in Coffea spp. Environ Exp Bot 74:194-204 (2011).

21 Scotti-Campos P, Pais IP, Partelli FL, Batista-Santos P and Ramalho JC, Phospholipids profile in chloroplasts of Coffea spp. genotypes differing in cold acclimation ability. J Plant Physiol 171: 243-249 (2014).

22 Van der Vossen $\mathrm{H}$, A critical analysis of the agronomic and economic sustainability of organic coffee production. Exp Agric 41:449-473 (2005).

23 DaMatta FM, Cláudio PR, Moacyr M and Raimundo SB, Ecophysiology of coffee growth and production. Braz J Plant Physiol 19:485-510 (2007).

24 Ferreira EPB, Partelli FL, Didonet AD, Marra GER and Braun H, Vegetative growth of Coffea arabica L. as affected by irrigation and climatic conditions of the Cerrado of Goiás State. Semina: Ciências Agrárias, Londrina, 34:3235-3244 (2013).

25 Rodrigues WP, Vieira HD, Campostrini E, Figueiredo FAMMA, Ferraz TM, Partelli FL et al. Physiological aspects, growth and yield of Coffea spp. in areas of high altitude. Aust J Crop Sci 10:666-674 (2016). 
26 CONAB (National Food Supply Company), Follow up of the Brazilian Crop: Coffee, Season 2015, Segundo Levantamento, vol. 1. CONAB, Brasília, pp. 1-59 (2014).

27 Dicks B, Countries of the World - Brazil. Evans Brothers, London (2005).

28 CONAB (National Food Supply Company), Acompanhamento da Safra Brasileira de Café: Safra 2014, vol. 1. CONAB, Brasília, pp. 1-61 (2013).

29 Ministério da Agricultura, Café no Brasil. Ministry of Agriculture (2015). Available: http://www.agricultura.gov.br/assuntos/politica-agrico la/cafe/cafeicultura-brasileira [26 June 2017].

30 Vilela PS and Rufino JLS, Caracterização da Cafeicultura de Montanha de Minas Gerais. INAES, Belo Horizonte, p. 300 (2010).

31 Alvares CA, Stape JL, Sentelhas PC, Gonçalves JLM and Sparovek G, Köppen's climate classification map for Brazil. Meteorologische Zeitschrift (Stuttgart) 22:711-728 (2014).

32 Camargo MBP, The impact of climatic variability and climate change on arabica coffee crop in Brazil. Bragantia 69:239-247 (2010).

33 Fazuoli IC, Thomaziello RA and Camargo MBP, Aquecimento global, mudanças climáticas e a cafeicultura paulista. O Agronômico 59:19-20 (2007).

34 Bergo CL, Pereira RCA and Sales F, Avaliação de genótipos de cafeeiros arábica e robusta no estado do Acre. Ciência e Agrotecnologia 32:11-16 (2008).

35 Camargo AP and Camargo MBP, Definição e esquematização das fases fenológicas do cafeeiro arábica nas condições tropicais do Brasil. Bragantia 60:65-68 (2001).

36 Marcolan AL, Ramalho AR, Mendes AM, Teixeira CAD, Fernandes CF, Costa JNM et al., Cultivo dos Cafeeiros Conilon e Robusta para Rondônia, 3. ed. rev. atual. Porto Velho, Embrapa Rondônia: EMATER-RO (2009). (Sistema de Produção/Embrapa Rondônia, ISSN 0103-1668; 33.) Available: http://www.cpafro.embrapa.br/ [30 June 2015].

37 Silva EA, DaMatta FM, Ducatti C, Regazzi AJ and Barros RS, Seasonal changes in vegetative growth and photosynthesis of arabica coffee trees. Field Crops Res 89:349-357 (2004).

38 Box GEP and Jenkins GM, Time Series Analysis: Forecasting and Control, revised edition. Holden-Day, San Francisco (1976).

39 Coelho C, Uvo C, Ambrizzi T, Exploring the impacts of the tropical Pacific SST on the precipitation patterns over South America during ENSO periods. Theor Appl Climatol 71:185-197 (2002).
40 Grimm AM, The El Nino impact on summer monsoon in Brazil: Regional processes versus remote influences. J Clim 16:263-280 (2003).

41 Minuzzi RB, Sediyama GC, Costa JMN and Vianello RL, Influência da La Niña na estação chuvosa da região sudeste do Brasil. Revista Brasileira de Meteorologia 22:345-353 (2007).

42 Zhang Y, Wallace PS and Battisti DS, ENSO-like interdecadal variability: 1900-93. J Clim 10:1004-1020 (1997).

43 Mendes ANG, Carvalho GR, Botelho CE, Fazuoli LC and Silvarolla MB, História das primeiras cultivares de café plantadas no Brasil, in Cultivares De Café: Origem, Características E Recomendações, ed. by Carvalho CHS. Embrapa Café, Brasília, pp. 157-226 (2008).

44 Chalfoun SM and Reis PR, A história da cafeicultura no Brasil, in Café Arábica do Plantio à Colheita, vol. 1, ed. by Reis PR and Cunha RL. U.R. EPAMIG SM, Lavras, pp. 23-85 (2010).

45 Marengo JA and Camargo CG, Surface air temperature trends in southern Brazil for 1960-2002. Int J Clim 28:893-904 (2008).

46 de los Milagros Skansi M, Brunet M, Sigró J, Aguilar E, Groening JAA, Bentancur $\mathrm{OJ}$ et al., Warming and wetting signals emerging from analysis of changes in climate extreme indices over South America. Global Planet Change 100:295-307 (2013).

47 Quintana-Gomez RA, Trends of maximum and minimum temperatures in northern South America. J Clim 12:2104-2112 (1999).

48 Vuille M, Bradley RS, Werner M and Keimig F, 20th century climate change in the tropical Andes: observations and model results. Clim Change 59:75-99 (2003).

49 New M, Hewitson B, Stephenson DB, Tsiga A, Kruger A, Manhique A et al., Evidence of trends in daily climate extremes over southern and West Africa. J Geophys Res D: Atmos 111:1-11 (2006).

50 Omondi PA, Awange JL, Forootan E, Ogallo LA, Barakiza R, Girmaw $\mathrm{GB}$ et al., Changes in temperature and precipitation extremes over the Greater Horn of Africa region from 1961 to 2010. Int J Clim 34:1262-1277 (2014).

51 Jha S, Bacon CM, Philpott SM, Méndez VE, Läderach P and Rice RA, Shade coffee: update on a disappearing refuge for biodiversity. Bioscience 64:416-428 (2014).

52 CONAB (National Food Supply Company), Follow up of the Brazilian Crop: Coffee, Season 2015, vol. 1. CONAB, Brasília, pp. 1-59 (2014).

53 McPhaden MJ, Zebiak SE and Glantz MH, ENSO as an integrating concept in earth science. Science 314:1739-1745 (2006). 